\begin{tabular}{|c|l|}
\hline Title & Stevioside enhances apoptosis induced by serum deprivation in PC12 cells \\
\hline Author(s) & $\begin{array}{l}\text { Takahashi, Kumiko; Sun, Y ongkun; Y anagiuchi, I kumi; Hosokawa, Toshiyuki; Saito, Takeshi; Komori, Miyako; } \\
\text { Okino, Tatsufumi; Kurasaki, Masaaki }\end{array}$ \\
\hline Citation & $\begin{array}{l}\text { Toxicology Mechanisms and Methods, 22(4), 243.249 } \\
\text { https://doi.org/40.3109/15376516.2012.658978 }\end{array}$ \\
\hline Issue Date & 2012-05 \\
\hline Doc URL & http://hdl.handle.net/2115/52718 \\
\hline Type & article (author version) \\
\hline File Information & TMM22-4_243-249.pdf \\
\hline
\end{tabular}

Instructions for use 


\section{Stevioside enhances apoptosis induced by serum deprivation in PC12 cells}

Kumiko Takahashi ${ }^{1}$, Yongkun Sun ${ }^{1}$, Ikumi Yanagiuchi ${ }^{1}$, Toshiyuki Hosokawa ${ }^{2}$, Takeshi Saito $^{3}$, Miyako Komori ${ }^{4}$, Tatsufumi Okino ${ }^{1,4} \&$ Masaaki Kurasaki ${ }^{1,4}$

${ }^{1}$ Environmental Adaptation Science, Division of Environmental Development, Graduate School of Environmental Science, Hokkaido University, 060-0810 Sapporo JAPAN

${ }^{2}$ Higher Education Research and Development Division, Institute for the Advancement of Higher Education, Hokkaido University, 060-0817 Sapporo JAPAN,

${ }^{3}$ Laboratory of Environmental Health Sciences, Faculty of Health Sciences, Hokkaido University, 060-0812 Sapporo JAPAN

${ }^{4}$ Group of Environmental Adaptation Science, Faculty of Environmental Earth Science, Hokkaido University, 060-0810 Sapporo JAPAN

Short Title: Stevioside accelerates apoptosis in PC12 cells

*Address correspondence to:

Dr. Masaaki KURASAKI, Faculty of Environmental Earth Science, Hokkaido University Sapporo 060-0810, Japan; Phone: +81-11-706-2243, Fax: +81-11-706-4864;

E-mail:kura@ees.hokudai.ac.jp 


\begin{abstract}
In our laboratory, using a PC12 cell system, we have been conducting studies on the effects of various chemicals on apoptosis, as it is considered to be an essential part of normal development, maintenance, and defense in organisms. Stevioside is a natural sweetener extracted from the leaves of Stevia rebaudiana. Since it is widely used as a sugar replacement, we decided to evaluate the toxicological effects of low concentrations of stevioside on apoptosis induced by serum deprivation using the PC12 cell system. We found, based on data from DNA electrophoresis and TUNEL signal assays, that stevioside enhanced apoptosis induced by serum deprivation. This enhancement was caused by increased expression of bax and of cytochrome $\mathrm{C}$ released into the cytosol. These findings suggest that stevioside affects the regulation of the normal apoptotic condition. Further investigation will be needed to clarify the detailed the mechanism of the enhancement due to the treatment with stevioside.
\end{abstract}

Keywords; apoptosis, bcl-2 family, cytochrome c, PC12 cells, stevioside

Abbreviations: EGTA; ethylene glycol tetraacetic acid, LD50; 50\% lethal dose, HEPES; 4-(2-hydroxyethyl)-1-piperazineethanesulfonic acid, PMSF; phenylmethylsulfonyl fluoride 


\section{Introduction}

Stevioside is a natural sweetener extracted from leaves of Stevia rebaudiana (Bertoni). The metabolism of stevioside has been investigated in relation to the possible formation of steviol. It was concluded that stevia and stevioside are safe when used as a sweetener (Geuns 2003). In $0.4 \%$ solution, stevioside tastes about 300 times sweeter than sucrose. The presence of steviolbioside and rebaudioside B in extracts might be due to artifacts of the extraction procedure (Kennelly 2002).

The stevia plant, its extracts, and stevioside have been used as sweeteners in South America, Japan, China, and in different countries of the EU. In Brazil, Korea and Japan, stevia leaves, stevioside and highly refined extracts are officially used as low-calorie sweeteners (Mizutani and Tanaka 2002). In the USA, powdered stevia leaves and refined extracts from the leaves have been used as dietary supplements. In 2000, the European Commission refused to accept stevia or stevioside as a novel food because of a lack of critical scientific reports on stevia and the discrepancies between cited studies with respect to possible toxicological effects of stevioside (Kinghorn 2002).

The toxicology and safety of stevioside used as a sweetener were reviewed by Huxtable (2002). An acceptable daily intake (ADI) of $7.9 \mathrm{mg}$ stevioside/kg body weight (BW) was calculated (Xili et al. 1992). Stevioside has low acute oral toxicity in the mouse, rat and hamster. An oral $\mathrm{LD}_{50}$ of between 8.2 and $17 \mathrm{~g} / \mathrm{kg} \mathrm{BW}$ was found (Toskulkao et al. 1997). In hamsters the $\mathrm{LD}_{50}$ levels of steviol (90\% purity), the aglycone of stevioside were 5.2 and $6.1 \mathrm{~g} / \mathrm{kg}$ BW for male and female animals, respectively. In rats and mice the $\mathrm{LD}_{50}$ was above $15 \mathrm{~g} / \mathrm{kg} \mathrm{BW}$ demonstrating that of the tested animals hamsters are much more sensitive to steviol (Toskulkao et al. 1997). In chronic subacute toxicity studies with rats for 3 months and with hamsters over several 
generations, a no effect level (NOEL) higher than $2.5 \mathrm{~g} / \mathrm{kg} \mathrm{BW}$ was found (Aze et al. 1991; Yodyingyuad et al. 1991). From these reports, the acceptable daily intake (ADI) can be deduced to be $25 \mathrm{mg} / \mathrm{kg} \mathrm{BW}$ (safety factor 100) (Geuns 2003). It has been shown that applied stevioside has no effect on fertility, mating performance, pregnancy, the number of fetuses, or the growth and fertility of offspring (Yodyingyuad et al., 1991; Usami et al., 1995). In addition, Geuns (2003) concluded that stevioside showed no carcinogenicity (Suttajit et al. 1993). Curry and Roberts (2008) and Curry et al. (2008) reported that a derivative of stevioside, rebaudioside A, showed no toxicity in rats after dietary treatment. Wasuntarawat et al. (1998) reported that no dose-related teratogenesis or embryo toxicity of stevioside was detected. Thus the safety of stevioside has been evaluated in mutagenic, subchronic and chronic studies. Most importantly, developmental studies have been conducted. These studies concluded that stevioside was not mutagenic, had low toxicity and was not a developmental toxin.

Recently, in our laboratory, using a PC12 cell (rat pheochromocytoma) system (Yamanoshita et al. 2000), we have been conducting risk assessment of chemicals to confirm their effects on apoptosis. We observed that chemical substances showing no toxicity affected the apoptotic reaction at low doses when by using this method. Apoptosis is induced in PC12 cells, when they are cultured in serum-free medium. The apoptotic PC12 cells exhibit DNA fragmentation (Batistatou and Greene 1993). Thus these cells have proven to be a useful system for studying whether chemical substances induce and/or affect apoptosis induced by serum deprivation. In summary, this system can clarify the total effects of chemical substances on apoptosis and/or apoptotic reactions.

Apoptosis is a physiological cell death mechanism that is commonly associated with 
programmed events necessary for the differentiation and development of individuals and organs (Kerr et al. 1972; Maroto and Perez-Polo 1997). It is regulated and executed by two major protein families, the Bcl-2 and caspase families, which are highly conserved from worms to humans (Spanos et al. 2002). The Bcl-2 family, which is involved in the regulation of caspase activity, is subdivided into pro-apoptotic (for example, Bax and Bad) and anti-apoptotic (for example, Bcl-2) members (Tujimoto and Shimizu 2000).

In this study, the effects of stevioside on apoptosis and apoptotic reactions were investigated using the PC12 cell system.

\section{Materials and methods}

\section{Materials}

PC12 cells were purchased from the American Type Culture Collection (USA and Canada). Dulbecco's modified Eagle's medium (DMEM), streptavidin-conjugated peroxidase, o-phenylendiamine dihydrochloride (OPD), and Stevia rebaudiana bertoni leaves were obtained from Sigma-Aldrich (St. Louis, MO USA). Concentrated stevia was purchased from Takeda Pharmaceutical Laboratories Co., Ltd. (Shinagawa, Japan). Fetal bovine serum (FBS) was bought from HyClone (Rockville, MD USA). Trypan blue stain solution (0.5\%) was from Nacalai Tesque (Kyoto, Japan). Biotin-16-2'-deoxy-uridine-5'-triphosphate, proteinase $\mathrm{K}$ and the blocking reagent were from Roche Diagnostics (Mannheim, Germany). Terminal deoxynucleotidyl transferase (TdT) was from Toyobo (Osaka, Japan). Monoclonal antibodies against Bax, and cytochrome $\mathrm{C}$ were from Oncogene Research Products (Boston, MA, USA) and Santa Cruz Biotechnology (Santa Cruz, USA), respectively. Biotinylated donkey anti-mouse 
immunoglobulin was from Amersham Pharmacia Biotech (Buckinghamshire, UK). Other chemicals were of analytical regent grade. The leaves of stevia were treated with ethanol to extract stevioside.

\section{LC/MS conditions for stevia}

The commercial available stevioside and extract of stevia obtained by ethanol extraction for 7 days were separated on a Develosil $\mathrm{NH}_{2}-5$ column $(2.0 \mathrm{~mm}$ i.d. $\times 150 \mathrm{~mm}$; NOMURA Chemical, Aichi, Japan) with an isocratic solvent system consisting of acetonitrile-water $(60: 40, \mathrm{v} / \mathrm{v})$ at a flow rate of $0.2 \mathrm{ml} / \mathrm{min}$. The analysis was carried out at $40^{\circ} \mathrm{C}$ with a Bruker Daltonics micro TOF focus mass spectrometer.

\section{Cell culture}

PC12 cells were maintained in DMEM supplemented with 10\% FBS in a humidified incubator at $37^{\circ} \mathrm{C}$ and $5 \% \mathrm{CO}_{2}$. The cells were preincubated in $25 \mathrm{~cm}^{2}$ flasks overnight, and then the medium was replaced with serum/serum-free DMEM with or without stevioside. When the medium was changed to serum-deprived medium, cells in the flask were washed twice with serum-free DMEM.

\section{Cell viability}

Cell viability was measured by trypan blue exclusion assay. PC12 cells were incubated in DMEM containing serum with 0 to $10,000 \mathrm{ng} / \mathrm{ml}$ stevioside for $72 \mathrm{hr}$. After the incubation, cells were stained in $0.25 \%$ trypan blue solution in phosphate-buffered saline. Total cells and trypan blue-stained cells were counted using a hemocytometer. Cell viability was expressed as a percentage against the total cell number in each 
experiment. Each experiment was repeated at least 3 times.

\section{Nuclear DNA isolation from PC12 cells}

The PC12 cells were treated with stevioside under the various conditions. Genomic DNA was isolated by the method of Yamanoshita et al. (2000). The cells were washed with $10 \mathrm{mM}$ Tris- $\mathrm{HCl}$ buffer, $\mathrm{pH}$ 7.4, containing $150 \mathrm{mM} \mathrm{NaCl}$, and harvested using a scraper. They were then centrifuged at 2,000 rpm for $10 \mathrm{~min}$ and the supernatant was removed. The cells were incubated with $10 \mathrm{mM}$ Tris-5 mM HCl, $0.1 \mathrm{M}$ EDTA, $0.5 \%$ SDS, and $20 \mu \mathrm{g} / \mathrm{ml}$ pancreatic RNase for $1 \mathrm{hr}$ at $37^{\circ} \mathrm{C}$. Proteinase $\mathrm{K}$ was added to the suspension up to $100 \mu \mathrm{g} / \mathrm{ml}$, and the enzyme reaction was carried out for $3 \mathrm{hr}$ at $50^{\circ} \mathrm{C}$. The genomic DNA was extracted with phenol and chloroform. The obtained DNA was resuspended in $89 \mathrm{mM}$ Tris-borate buffer, $\mathrm{pH}$ 8.1, containing 1 mM EDTA (1×TBE).

The ladder pattern of DNA was analyzed by agarose gel electrophoresis. From 3 to 5 $\mu \mathrm{g}$ of DNA was subjected to electrophoresis on $1.5 \%$ agarose gel. After the electrophoresis, DNA was visualized by staining with ethidium bromide under UV illumination.

\section{Quantification of DNA fragmentation in PC12 cells by the TdT mediated dUTP-biotin nick end labeling (TUNEL) method}

The PC12 cells were cultured in the serum/serum-free medium with 0 to $10,000 \mathrm{ng} / \mathrm{ml}$ stevioside for $72 \mathrm{hr}$, after which nuclear DNA was isolated from the cells. The obtained DNA was resuspended in $1 \times \mathrm{TBE}$ buffer, and equal amounts of DNA were put into a 96-well plate. Quantification of DNA damage in PC12 cells was measured by the method of Kurasaki et al. (2001). The plate was incubated at $4{ }^{\circ} \mathrm{C}$ overnight. After the 
incubation, the plate was washed with the $40 \mathrm{mM}$ Tris- $\mathrm{HCl}$ buffer, $\mathrm{pH} 7.4$, containing $150 \mathrm{mM} \mathrm{NaCl}$. Nonspecific binding sites were blocked with $2 \%$ blocking reagent in the same buffer for $30 \mathrm{~min}$. Then the plate was washed with same buffer twice. TdT reaction was performed in a reaction mixture consisting of $30 \mathrm{mM}$ Tris- $\mathrm{HCl}$ buffer, $\mathrm{pH}$ 7.4, containing $140 \mathrm{mM}$ sodium cacodylate, $1 \mathrm{mM}$ cobalt chloride, 0.1 unit of TdT and $2 \mathrm{nM}$ biotinylated-dUTP at $37^{\circ} \mathrm{C}$ for $1.5 \mathrm{hr}$. After the reaction, the plate was washed three times with the same buffer, and then was incubated with streptavidin-conjugated peroxidase (1:400 diluted) for $1 \mathrm{hr}$. Following this, the plate was washed five times with the same buffer. After washing, $0.1 \%$ OPD in $50 \mathrm{mM}$ phosphate-citrate buffer, $\mathrm{pH}$ 5.0, containing $0.03 \%$ sodium perborate was added to each well and incubated for $0.5 \mathrm{hr}$ at $37^{\circ} \mathrm{C}$. Then, $\mathrm{HCl}$ was added to stop the enzyme reaction. Absorbance at $495 \mathrm{~nm}$ was measured with a Microplate Reader model 450 (BIO-RAD).

\section{Western blot analysis using antibodies against Bax and cytochrome c}

The PC12 cells were cultured in DMEM containing 10\% FBS with 0 to $10,000 \mathrm{ng} / \mathrm{ml}$ stevioside for $72 \mathrm{hr}$. After this, the cells were washed with $40 \mathrm{mM}$ Tris-HCl buffer, $\mathrm{pH}$ 7.4, containing $150 \mathrm{mM} \mathrm{NaCl}$, and harvested using a scraper. The obtained cells were centrifuged at $2,000 \mathrm{rpm}$ for $3 \mathrm{~min}$ to remove the supernatants. Then they were resuspended in lysis buffer consisting of $2 \mathrm{mM}$ HEPES, $100 \mathrm{mM} \mathrm{NaCl}, 10 \mathrm{mM}$ EGTA, $1 \mathrm{mM}$ PMSF, $1 \mathrm{mM} \mathrm{Na} \mathrm{VO}_{4}, 0.1 \mathrm{mM} \mathrm{Na} \mathrm{MoO}_{4}, 5 \mathrm{mM} \beta$-glycerophosphoric acid disodium salt, $50 \mathrm{mM} \mathrm{NaF}, 1 \mathrm{mM} \mathrm{MgCl}_{2}, 2 \mathrm{mM}$ DTT and $1 \%$ Triton X-100 and disrupted by sonication for $1 \mathrm{~min}$ with a Sonifier 250 (Branson). The cell debris and unbroken cells were removed by centrifugation. Following this $20 \mu \mathrm{g}$ of proteins was added to each well. 
Western blot analyses were carried out by the method described previously (Aoki et al. 2008). Protein bands that responded to antibodies were detected with an enhanced chemiluminescence system after washing of the membrane with washing buffer.

\section{Statistical analysis}

Each value is expressed as the mean \pm SEM. Statistical analyses were performed by one-way analysis of variance (ANOVA), followed by the Fisher's test.

\section{Results}

\section{Structural identification by LC mass}

Using the LC mass, the components of stevioside and the extract of stevia were determined as shown in Figure 1. There were five main ingredients, Stevioside, rebaudioside $\mathrm{A}$, rebaudioside $\mathrm{C}$, dulcoside $\mathrm{A}$ and rubusoside. The levels of ingredients of the extract of stevia were higher than those of stevioside; however, the component ratios of the extract of the stevia leaf were almost same as for stevioside. Therefore, in this study, stevioside was used in the following experiment.

\section{Cell viability}

To confirm whether stevioside exhibited cell toxicity, cell viability was measured by trypan blue staining after the PC12 cells were exposed to 0 to $10,000 \mathrm{ng} / \mathrm{ml}$ stevioside for $72 \mathrm{hr}$. As shown in Figure 2, no significant differences of viability were observed in the cells exposed to 1 to $10,000 \mathrm{ng} / \mathrm{ml}$ stevioside in comparison with those of cells cultured in serum-medium without stevioside. A significant decrease in viability was observed in the cells cultured in the serum-free medium without stevioside because 
apoptosis was induced by serum deprivation. These results indicated that stevioside was not toxic in this cell system and coincided with the data reported by Curry and Roberts (2008) and Curry et al. (2008).

\section{Detection of DNA fragmentation by agarose gel electrophoresis}

Apoptosis has been reported to be induced by serum deprivation in PC12 cells (Maroto and Perez-Polo 1997). To clarify whether stevioside affected the apoptosis induced by serum deprivation and/or induced apoptosis itself, DNA fragmentation of the PC12 cells cultured in medium containing serum and serum-free medium containing stevioside was observed by electrophoresis (Figure 3).

The morphological characteristics of apoptosis are frequently accompanied by multiple cleavage of DNA into 180-200 base pairs. The oligonucleosomal-sized fragments can be visualized as a characteristic DNA ladder following agarose gel electrophoresis (Woodgate et al. 1999). As shown in Figure 3A, the DNA ladder pattern was hardly observed in the cells cultured in the medium with serum containing 0 to $10,000 \mathrm{ng} / \mathrm{ml}$ stevioside. These results indicated that stevioside itself could not induce apoptosis in the PC12 cells. On the other hand, when apoptosis was induced by serum deprivation (Figure 3B), DNA ladder patterns were observed in the cells incubated in the serum-free medium containing 0 to $10,000 \mathrm{ng} / \mathrm{ml}$ stevioside. Furthermore, it was noted that the DNA ladder patterns increased with addition of more than $10 \mathrm{ng} / \mathrm{ml}$ stevioside. The results suggested that stevioside might enhance the apoptosis induced by serum deprivation in the PC12 cells.

\section{Determination of DNA fragmentation quantified by the TUNEL method}


DNA fragmentation occurs via the action of endonucleases. The TUNEL method specifically labels DNA ends generated by endonuclease activity (Gollapudi et al. 1999). Quantification of DNA ladders was carried out by the TUNEL method to evaluate the degree of apoptosis in the cells treated with 0 to $10,000 \mathrm{ng} / \mathrm{ml}$ stevioside for 3 days.

As shown in Figure 4A, the TUNEL signals in the cells cultured in the serumcontaining medium with stevioside increased slightly; however, there was no significant difference among the experimental groups. The results were in good agreement with data for DNA electrophoresis from the cells cultured in the serum-containing medium with stevioside (Figure 3A). This indicated that stevioside could not induce apoptosis.

On the other hand, the TUNEL signals in the cells cultured in serum-free medium containing steviosides increased significantly as shown in Figure 4B, as demonstrated by ANOVA. These results also coincided with the results shown in Figure 3B and confirm the enhancement of apoptosis caused by addition of steviosides.

\section{Expression of Bax and released amounts of cytochrome $\mathrm{C}$ detected by Western blot}

\section{analyses}

To confirm whether stevioside affected the pathway of apoptosis via the bcl-2 family, Western blot analyses using the cell lysis from PC12 cells treated with 0 to 10,000 $\mathrm{ng} / \mathrm{ml}$ stevioside were performed using the monoclonal antibodies against Bax and cytochrome C.

It has been reported that apoptosis is induced by release of cytochrome $\mathrm{C}$ from mitochondria into cytosol. After treatment of PC12 cells cultured in serum-free medium with stevioside, the contents of Bax (Figure 5A) and cytochrome $\mathrm{C}$ (Figure 5B) were increased significantly as compared with those in cells treated without stevioside. 


\section{Discussion}

In this study, we confirmed that stevioside enhanced apoptosis induced by serum deprivation. This finding was supported by the results of electrophoresis (Figure 3), TUNEL signals (Figure 4) and analyses of Western blots (Figure 5). The enhanced effects were observed when more than $10 \mathrm{ng} / \mathrm{ml}$ stevioside was added to the medium for PC12 cells.

The influence of some endocrine disrupters on apoptosis induced by serum deprivation was investigated using PC12 cells (Yamanoshita et al. 2000; Yamanoshita et al. 2001; Aoki et al. 2004; Aoki et al. 2008). It was reported that tributyl tin and 2,4,5,T inhibited the apoptosis completely and that these endocrine disrupters might affect infants and neonates. Nonylphenol enhanced apoptosis induced by serum deprivation, similar to stevioside (Figure 3; Aoki et al. 2004). These studies revealed effects of chemicals on apoptosis induced by serum deprivation. This means that these chemicals affect normal regulation of the apoptosis. Stevioside is widely used for sweeteners as it is believed to be a nontoxic food additive. The pharmacokinetics of stevioside have been well documented by in vivo and in vitro studies in rats, but its metabolism and that of its related compounds in humans is basically unknown (Koyama et al. 1997). Brusick (2008) reported that neither stevioside nor its aglycone metabolite steviol have been shown to react directly with DNA or demonstrate genotoxic damage in assays relevant to human risk. He also concluded that stevioside did not pose a risk of genetic damage following human consumption.

In this study, as shown in Figure 2, stevioside had no cell toxicity. However, it was found that stevioside enhanced apoptosis in PC12 cells cultured in serum-free medium, 
although stevioside itself could not induce apoptosis in the PC12 cells (Figure 3). As shown in Figure 4, the TUNEL signals in the cells cultured in the serum-free medium containing stevioside increased significantly. Dybdahl et al. (2003) reported the TUNEL signals were significantly induced in the liver in the dose range from $0.8-20 \mathrm{mg}$ of diesel particles/kg. In this study, the increases of DNA damage and DNA ladders in the serum-deprived cells exposed to stevioside were confirmed to be due to enhanced apoptosis. It is therefore suggested that stevioside may affect some apoptotic pathway.

Previously Aoki et al. (2004) reported that nonylphenol enhanced apoptosis induced by serum deprivation in PC12 cells. It has been reported that apoptosis or programmed cell death is a highly regulated process and there are a number of pro-apoptotic (e.g., Bax, Bad) and anti-apoptotic (e.g., Bcl-2) proteins (Reed 1997; Tsujimoto 1998). Apoptosis can be triggered by signals arising from within the cell or by extrinsic death activators. There are two major apoptotic pathways. The intrinsic apoptotic pathway involves the release cytochrome $\mathrm{C}$ from mitochondria. The extrinsic apoptotic pathway is mediated by the TNF receptor (TNF-R) superfamily of death receptors. One of the early steps committing a cell to apoptosis is the activation of caspases (Thornberry et al. 1997). As shown in Figure 5 in this study, Western blot analyses using the cell lysis from PC12 cells after treatment with 0 to $10,000 \mathrm{ng} / \mathrm{ml}$ stevioside revealed that contents of Bax and cytochrome $\mathrm{C}$ were increased as compared with those in cells treated without stevioside. Bax is a pro-apoptotic Bcl-2 family member that is thought to bind Bcl-2 and thus to block the anti-apoptotic function of Bcl-2. From our results, it was thought that the expression of Bax was activated by addition of stevioside, and that Bax activated membrane permeability and promoted cytochrome $\mathrm{C}$ release. It is hypothesized that, in PC12 cells, synthesis of reactive oxygen species (ROS) catalyzed 
by chemical substances such as stevioside damages DNA (Er et al. 2006). ROS trigger the transactivation of $\mathrm{p} 53$, resulting in expression of Bax. It appears that the stevioside-enhanced apoptotic pathway is involved in the release cytochrome $\mathrm{C}$ from mitochondria, but not the pathway mediated by the TNF-R. Thus, it is considered that stevioside enhances peroxidative stress in the cells.

\section{Conclusion}

Stevioside enhanced the apoptosis induced by serum-deprivation. This enhancement was thought to be caused by an increase of cytochrome $\mathrm{C}$ released into the cytosol. In addition, the expression of bax was also increased by the addition of stevioside. Although stevioside did not show serious cytotoxicity, it is considered that stevioside enhances peroxidative stress in PC12 cells at a low concentration. Further investigation will be needed to clarify the detailed mechanism of enhancement of apoptosis, and to confirm whether the same reaction occurs in mammalians.

\section{Acknowledgments}

This research was supported by a Grants-in-Aid from the Japan Society for the Promotion of Science (No. 23655139 for Kurasaki).

\section{Declaration of interest}

The authors declare that there are no conflicts of interest.

\section{References}

Aoki K, Egawa M, Saito T, Hosokawa T, Kurasaki M. (2008). Effects of 
gamma-hexachlorocyclohexane on apoptosis induced by serum deprivation in PC12 cells. J Environ Sci Health B, 43, 471-5.

Aoki M, Kurasaki M, Saito T, Seki S, Hosokawa T, Tahakahashi Y, Fujita H, Iwakuma T. (2004). Nonylphenol enhances apoptosis induced by serum deprivation in PC12 cells. Life Sci, 74, 2301-12.

Aze Y, Toyoda K, Imaida K, Hayashi S, Imazawa T, Hayashi Y, Takahashi M. (1991). Subchronic oral toxicity study of stevioside in F344 rats. Bull Nat Inst Hyg Sci, 109, $48-54$.

Batistatou A, Greene LA. (1993). Internucleosomal DNA cleavage and neuronal cell survival/death. J Cell Biol, 122, 523-32.

Brusick DJ. (2008). A critical review of the genetic toxicity of steviol and steviol glycosides. Food Chem Toxicol, 46, S83-S91.

Curry LL, Roberts A. (2008). Subchronic toxicity of rebaudioside A. Food Chem Toxicol, 46, S11-20.

Curry LL, Roberts A, Brown N. (2008). Rebaudioside A: Two-generation reproductive toxicity study in rats. Food Chem Toxicol, 46, S21-30.

Dybdahl M, Risom L, Møller P, Autrup H, Wallin H, Vogel U, Bornholdt J, Daneshvar B, Dragsted LO, Weimann A, Poulsen HE, Loft S. (2003). DNA adduct formation and oxidative stress in colon and liver of Big Blue rats after dietary exposure to diesel particles. Carcinogenesis, 159, 1759-66.

Er E, Oliver L, Cartron PF, Juin P, Manon S, Vallette FM. (2006). Mitochondria as the target of the pro-apoptotic protein Bax. Biochim Biophys Acta, 1757, 1301-11.

Geuns JM. (2003). Stevioside. Phytochem, 64, 913-21.

Gollapudi L, Oblinger MM. (1999). Stable transfection of PC12 cells with estrogen 
receptor (ER): protective effects of estrogen on cell survival after serum deprivation. J Neurosci Res, 56, 99-108.

Huxtable RJ. (2002). Pharmacology and toxicology of stevioside, rebaudioside A, and steviol. In: Kinghorn AD, ed. Stevia, the Genus Stevia. Medicinal and Aromatic Plants-Industrial Profiles. Vol. 19. London and NY: Taylor and Francis, 160-77.

Kennelly EJ. (2002). Sweet and non-sweet constituents of Stevia rebaudiana (Bertoni) Bertoni. In: Kinghorn AD, ed. Stevia, the Genus Stevia. Medicinal and Aromatic Plants-Industrial Profiles. Vol. 19. London and NY: Taylor and Francis, 68-85.

Kerr JF, Wyllie AH, Currie AR. (1972). Apoptosis: a basic biological phenomenon with wide-ranging implications in tissue kinetics. Br J Cancer, 26, 239-257.

Kinghorn AD. (2002). Stevia, the Genus Stevia. Medicinal and Aromatic Plants-Industrial Profiles, Vol. 19. London and NY: Taylor and Francis.

Koyama E, Kitazawa K, Ohori Y, Kakegawa K, Fujino A, Ui M. (2003). In vitro metabolism of the glycosidc sweeteners, stevia mixture and enzymatically modified stevia in human intestinal microflora. Food Chem Toxicol, 41, 359-374.

Kurasaki M, Aoki M, Miura T, Seki S, Toriumi S, Hosokawa T, Okabe M, Numata T, Saito S, Saito T. (2001). A developed method of terminal deoxynucleotidyl transferase system for quantification of DNA damage caused by apoptosis. Ana Sci, 17, i1517-20.

Maroto R, Perez-Polo JR. (1997). BCL-2-related protein expression in apoptosis: oxidative stress versus serum deprivation in PC12 cells. J Neurochem, 69, 514-23.

Mizutani K, Tanaka O. (2002). Pharmacology and toxicology of stevioside, rebaudioside A, and steviol. In: Kinghorn AD, ed. Stevia, the Genus Stevia. Medicinal and Aromatic Plants-Industrial Profiles. Vol. 19. London and NY: Taylor 
and Francis, 178-95.

Reed JC. (1997). Double identity for proteins of the Bcl-2 family. Nature 387, 773-6.

Spanos S, Rice S, Karagiannis P, Taylor D, Becker DL, Winston RML, Hardy K. (2002). Caspase activity and expression of cell death genes during development of human preimplantation embryos. Reproduction, 124, 353-63.

Suttajit M, Vinitketkaumnuen U, Meevatee U, Buddhasukh D. (1993). Mutagenicity and human chromosomal effect of stevioside, a sweetener from Stevia rebaudiana Bertoni. Environ Health Perspect, 101, 53-6.

Thornberry NA, Rano TA, Peterson EP, Rasper DM, Timkey T, Garcia-Calvo M, Houtzager VM, Nordstrom PA, Roy S, Vaillancourt JP, Chapman KT, Nicholson DW. (1997). A combinatorial approach defines specificities of members of the caspase family and granzyme B. Functional relationships established for key mediators of apoptosis. J Biol Chem, 272, 17907-11.

Toskulkao C, Chaturat L, Temcharoen P, Glinsukon T. (1997). Acute toxicity of stevioside, a natural sweetener, and its metabolite, steviol, in several animal species. Drug Chem Toxicol, 20, 31-44.

Tsujimoto Y. (1998). Role of Bcl-2 family proteins in apoptosis: apoptosomes or mitochondria. Genes Cells, 3, 697-707.

Tujimoto Y, Shimizu S. (2000). Bcl-2 family: life-or-death switch. FEBS Lett, 466, 6-10.

Usami M, Sakemi K, Kawashima K, Tsuda M, Ohno Y. (1995) Teratogenicity study of stevioside in rats. Eisei Shikenjo Hokoku-Bull Nat Inst Hyg Sci, 113, 31-5.

Wasuntarawat C, Temcharoen P, Toskulkao C, Mungkornkarn P, Suttajit M, Glinsukon T. (1998). Developmental toxicity of steviol, a metabolite of stevioside, in the hamster. 
Drug Chem Toxicol, 21, 207-22.

Woodgate A, MacGibbon G, Walton M, Dragunow M. (1999). The toxicity of 6-hydroxydopamine on PC12 and P19 cells. Brain Res Mol Brain Res, 69, 84-92.

Xili L, Chengjiany B, Eryi X, Reiming S, Yuengming X, Haodong S, Zhiyian H. (1992). Chronic oral toxicity and carcinogenicity study of stevioside in rats. Food Chem Toxicol, 30, 957-65.

Yamanoshita O, Kurasaki M, Saito T, Takahashi K, Sasaki H, Hosokawa T, Okabe M, Mochida J, Iwakuma T. (2000). Diverse effect of tributyltin on apoptosis in PC12 cells. Biochem Biophys Res Commun, 272, 557-62.

Yamanoshita O, Saito T, Takahashi K, Hosokawa T, Okabe M, Ito K, Kurasaki M. (2001). 2,4,5-Trichloro-phenoxyacetic acid inhibits apoptosis in PC12 cells. Life Sci, 69, 403-8.

Yodyingyuad V, Bunyawong S. (1991). Effect of stevioside on growth and reproduction. Human Reprod, 6, 158-65. 


\section{Figure legends}

Figure 1. The ratios of compounds from stevioside and stevia extract.

Figure 2. Cell viability of PC12 cells treated with 0 to $10,000 \mathrm{ng} / \mathrm{ml}$ stevioside or stevia extract of for $72 \mathrm{hr}$ measured by trypan blue staining. PC12 cells cultured in the serum medium without steviosides for $72 \mathrm{hr}$ were used as a negative control. Error bars indicate SEM $(n=3)$.

Figure 3. Agarose gel electrophoresis of DNA extracted from PC12 cells cultured in serum-containing medium (A) and serum-free medium (B) for 3 days after treatment with 0 to $10,000 \mathrm{ng} / \mathrm{ml}$ stevioside.

Figure 4. Quantification of DNA fragmentation in PC12 cells cultured in serum-containing medium (A) and serum-free medium (B) with 0 to $10,000 \mathrm{ng} / \mathrm{ml}$ stevioside. Error bars indicate $\operatorname{SEM}(\mathrm{n}=3)$. ** means $\mathrm{P}<0.01$.

Figure 5. Western blot analyses for Bax (A) and cytochrome C (B) in PC12 cells cultured in the medium containing serum with 0 to $10,000 \mathrm{ng} / \mathrm{ml}$ stevioside. In the figure, typical patterns and mean intensities of staining of representative Western blot analysis are shown in the upper and lower panels, respectively. Error bars indicate SEM for bax $(\mathrm{n}=5)$ and cytochrome $\mathrm{C}(\mathrm{n}=4)$. * means $\mathrm{P}<0.05$. 


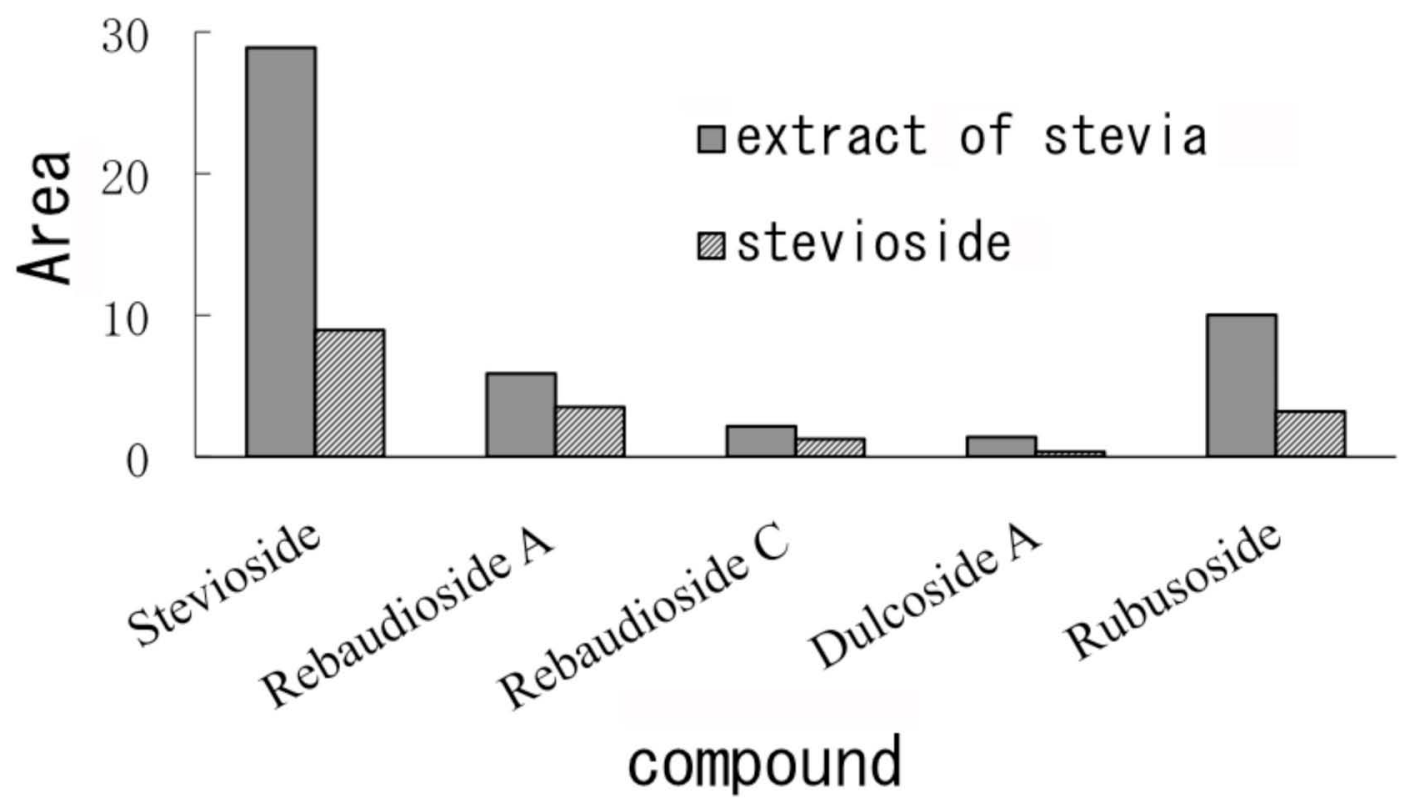




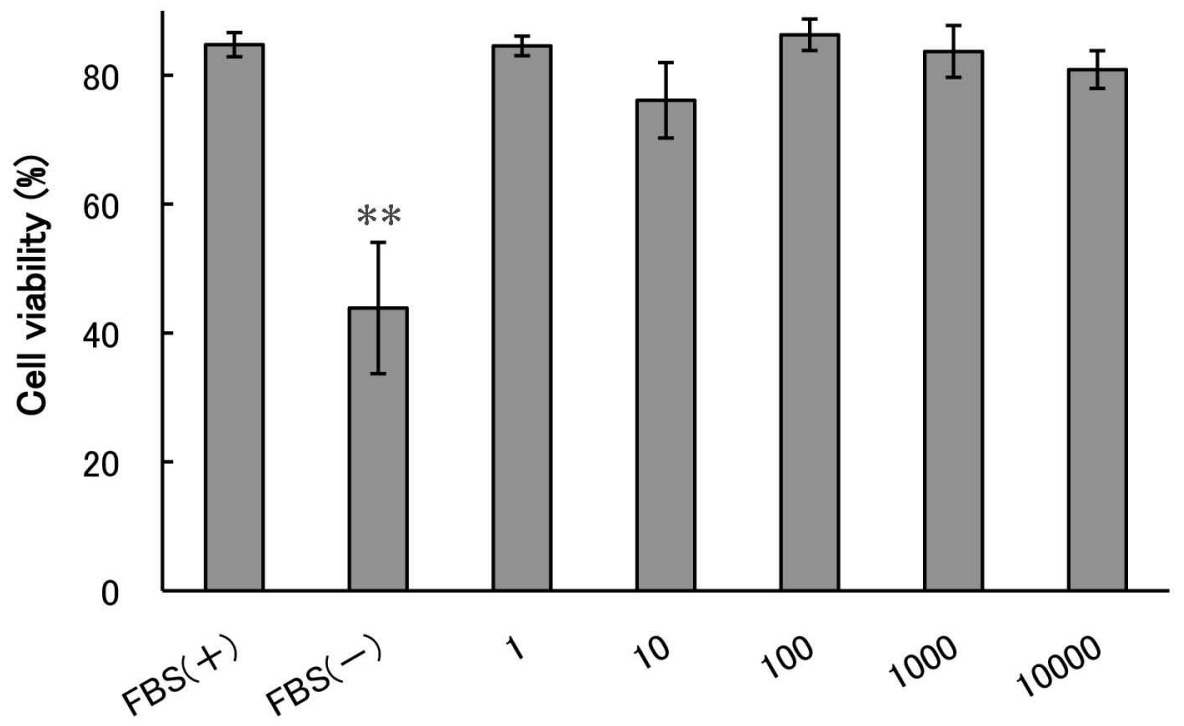

Exposed concentration of stevioside ( $\mathrm{ng} / \mathrm{ml})$ 


\section{FBS $(+)$ stevioside [ng/ml]}

\section{$\begin{array}{llllll}0 & 1 & 10 & 100 & 1000 & 10,000\end{array}$}

FBS $(-)$ stevioside $[\mathrm{ng} / \mathrm{ml}]$

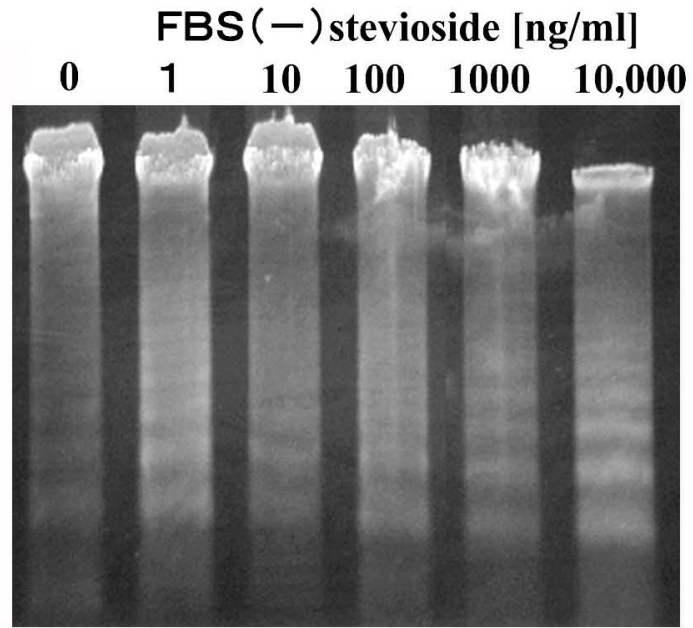



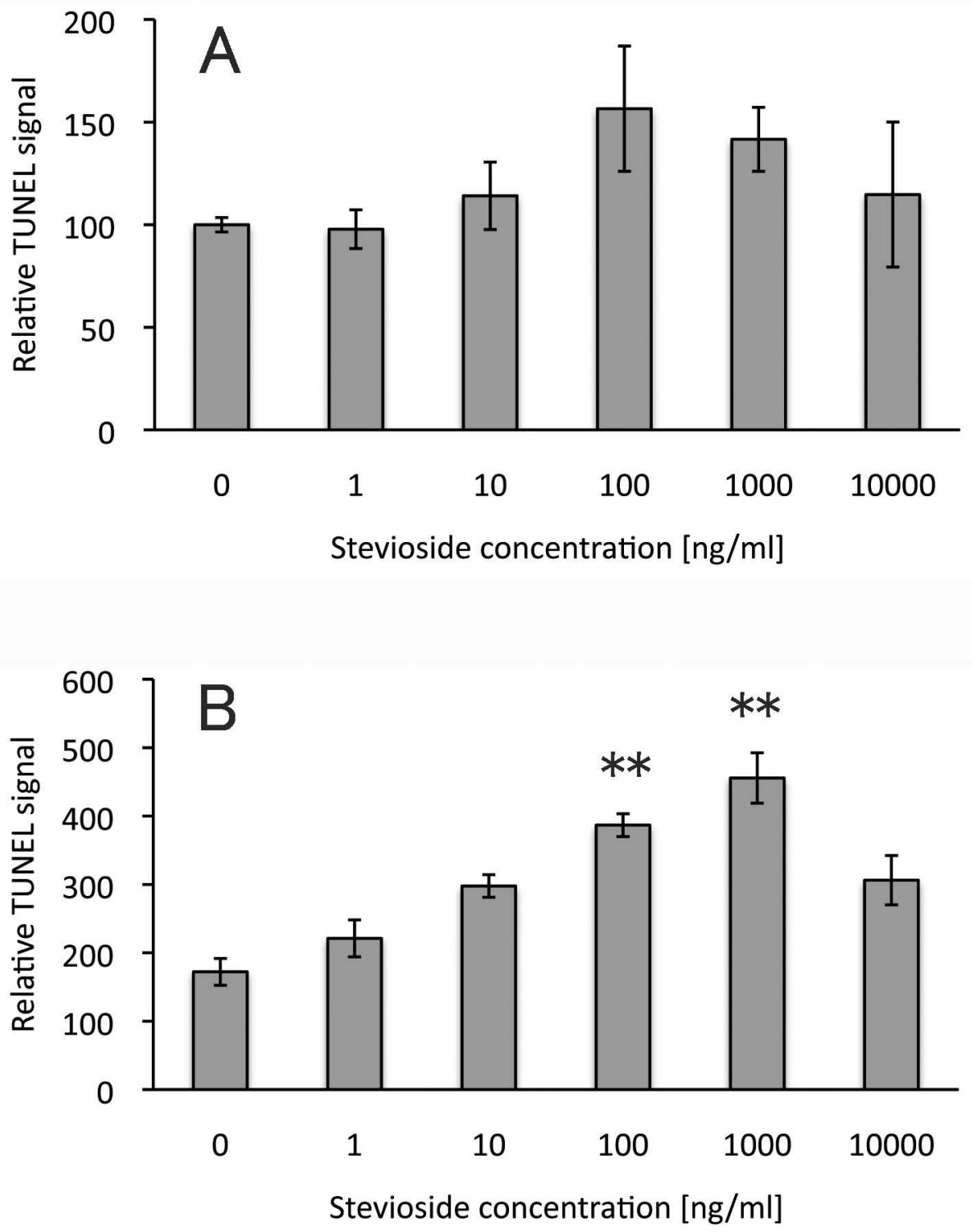

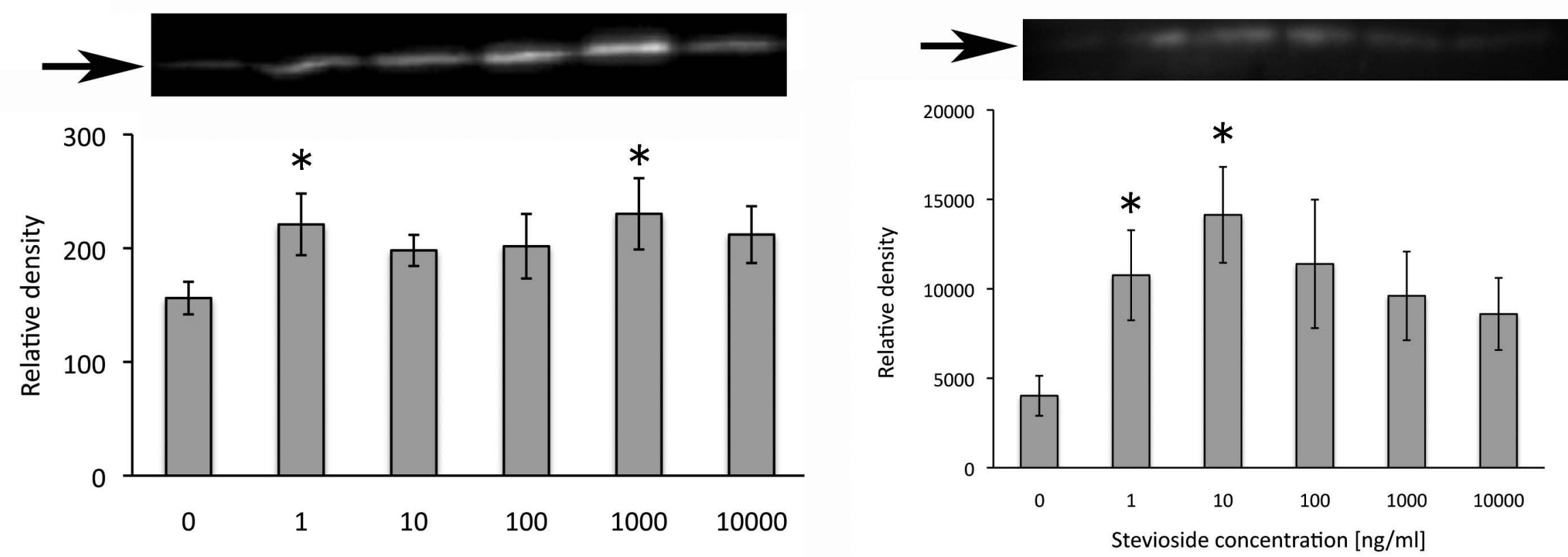

Stevioside concentration $[\mathrm{ng} / \mathrm{ml}]$ 